\title{
MORPHOLOGICAL CHANGES IN THE TISSUES OF THE RABBIT KNEE JOINT DUE TO EXPERIMENTAL OSTEOARTHRITIS AFTER THE USE OF MESENCHYMAL STEM CELLS
}

\author{
1Department of Surgery and Pathophysiology named after acad. I.O. Povazhenko, \\ National University of Life and Environmental Sciences of Ukraine, Kyiv, Ukraine \\ 2Department of Animal Anatomy, Histology and Pathomorphology named after academician \\ Vladimir G. Kas'janenko, National University of Life and Environmental Sciences of Ukraine, Kyiv, Ukraine \\ ${ }^{3}$ Institute of Biological Basis of Animal Production, Faculty of Biology, Animal Sciences \\ and Bioeconomy, University of Life Sciences in Lublin, Poland
}

\begin{abstract}
The purpose of the study was to investigate the regenerative processes in the knee joint of rabbits with experimental osteoarthritis after using of allogeneic bone marrow stem cells and a traditional treatment with the non-steroidal anti-inflammatory drug Meloxicam. For the experiment were used 27 male California rabbits (males). Three groups of animals were formed: a control group; the first experimental group treated by the traditional method; the second experimental group treated with allogeneic mesenchymal stem cells (MSC). Animals in the three groups were subjected to osteoarthritis of the knee joint by double injection of $3.44 \%$ retinol acetate into the joint cavity at a dose of $1 \mathrm{ml}$ at intervals of 7 days. Tissue from the affected site was sampled for histological examination at 7, 14 and 28 days. The histological sections were stained with haematoxylin-eosin and examined under a microscope. It has been established that intra-articular administration of $3.5 \times 10^{6}$ cells of allogeneic MSCs in experimental osteoarthritis contributes to the restoration of the superficial layer of cartilage, as evidenced by the formation of columns of chondrocytes in the middle layer of articular cartilage and the appearance of isogenic groups of cartilage cells with basophilic cytoplasm in the matrix, uniform articular surface. The use of the traditional method of treating rabbits using the drug Meloxicam is accompanied by incomplete chondrogenesis: part of the chondrocytes is localized in typical chambers, in some cases chondrocyte chambers did not differentiate; articular cartilage had unequal thickness, cell placement was uneven.
\end{abstract}

Key words: rabbits, knee joint, bone marrow, mesenchymal stem cells, osteoarthritis.

\section{INTRODUCTION}

The rabbit is of economic importance and is used as a meat, skin and wool supply animal and a laboratory animal. Increasingly, it also finds a place in homes as a room animal, kept for companionship. Osteoarthritis $(\mathrm{OA})$ is a dystrophic joint disease that underlies degenerative damage to the cartilage with subsequent destruction of the tissue of the epiphysis. Sclerotic changes in the subchondral bone, capsule hypertrophy, and reactive synovitis are observed in the joint (Felson 2006; Nöth et al. 2008; Bijlsma et al. 2011; Chaganti et al. 2011).

Corresponding author: Magdalena Gryzinska, Institute of Biological Basis of Animal Production, Faculty of Biology, Animal Sciences and Bioeconomy, University of Life Sciences in Lublin, Akademicka 13, 20-950 Lublin, Poland, e-mail: magdalena.gryzinska@up.lublin.pl 
Primary chronic osteoarthritis is an independent, polyetiological disease, while secondary osteoarthritis is a complication of the underlying joint disease, observed in $90 \%$ of cases in dogs of large breeds (such as sheepdogs, Great Danes, or St. Bernards). The most common cause, however, is micro- or macro-injury of the articular cartilage with subsequent degeneration, or a disturbance of the equilibrium of the joint, which leads to an increase in the load on certain parts of the articular cartilage, leading to its destruction. This can be associated with hip dysplasia, intra-articular fractures, or obesity. Some authors ascribe great importance to changes in the structures of the synovial fluid and impairment of its 'lubricating' properties (Maury et al. 2006; Bakker et al. 2017). Traditional treatments for such diseases in animals and humans are usually based on the use of non-steroidal anti-inflammatory drugs, as well as natural or synthetic corticosteroids. However, these are known to inhibit synthesis of proteins and a number of biologically active substances, which is often accompanied by gastropathy (peptic ulcer) (Singh 2012).

Irrespective of the etiology of the disease, the damage to the cartilage of the joints is a major factor in the pathogenesis of osteoarthritis. Treatment of articular cartilage defects is a complex orthopaedic problem. Due to the lack of blood supply and low metabolism resulting from the small number of cells per unit volume of tissue, complete reparative cartilage regeneration is only possible on small areas of damage. With extensive damage to cartilage, cartilage regeneration precedes the development of granulation tissue at the site of the defect (Melero-Martin et al. 2007; Huey et al. 2012).

In recent years, researchers have shown great interest in the use of cellular technologies for the treatment of damaged cartilage (Jones et al. 2007; Kolf et al. 2007; Melero-Martin at el. 2007; Mobasheri et al. 2009; 2014, Musumeci et al. 2014; Atala et al. 2019). Most of them are based on the introduction of a suspension of mesenchymal stem cells (MSCs) into the area of the defect (Nöth et al. 2008; Mokbel et al. 2011; Sing 2012; Diekman et al. 2013; Montoya et al. 2013).

Mesenchymal stem cells have low immunogenicity and immunosuppressive properties. These properties of MSCs are widely exploited in cell therapy (Mazurkevych et al. 2016, 2017, 2018; Kladnytska et al. 2019).

Therefore, the search for new treatments for chronic osteoarthritis, as well as modifications and improvements of the old approaches of conservative and surgical treatment, remain relevant and require further research.

The aim of the study was to investigate the effect of undifferentiated allogeneic mesenchymal stem cells on restorative processes in the knee joint of rabbits with experimental osteoarthritis.

\section{MATERIALS AND METHODS}

Animal experiments were carried out in accordance with the requirements of the "General Ethical Principles for Conducting Animal Experiments" approved by the I National Congress on Bioethics in Kyiv in 2004 year and the provisions of the European Convention for the Protection of Vertebrate Animals Used in Experimental and Other scientific purposes" in Strasbourg in 1986 year, the Law of Ukraine "On protection of animals against cruel treatment" (2006). 
Mesenchymal stem cells were obtained from the red marrow of rabbit femur. Before the start of the study, the operative production sedated the animal in an internal environment injected with acepromazine containing $3 \mathrm{mg}$ of xylazine and $1 \mathrm{mg}$ of acepromazine per $1 \mathrm{~kg}$ of animal body weight. In the place of surgical access was made an infiltrational anesthesia of the skin and subcutaneous tissue of $0.5 \%$ dissolved novocaine. $1.5 \times 1.5 \mathrm{~cm}$ operative field was selected and treated twice with a $5 \%$ alcohol solution of iodine, after which the skin in the area of the operative field on the northern diameter was placed to the side and pierced with a scalpel blade. After that, a needle for bone marrow puncture with mandrene was pierced with tissues adjacent to the bone. Moderately pressing the needle with simultaneous slow pronational movements propelled the needle into the thickness of the spongy bone by $0.5 \mathrm{~cm}$. The mandrine was removed and a $10 \mathrm{~cm}^{3}$ syringe with heparin 2-3 OD per $1 \mathrm{~cm}^{3}$ of expected volume of bone marrow aspirate was attached to the cannula of the needle. The bone marrow was then aspirated.

After receiving the bone marrow, the needle, without detaching from the syringe, was removed and a sterile cotton-gauze swab was applied to the skin in the puncture site (after its displacement to the previous position) for 1-2 minutes. After stopping bleeding, the skin in the puncture site was treated with a $5 \%$ alcohol solution of iodine.

The resulting cell mass from rabbit bone marrow was cultured in standard environment: DMEM - $80 \%$, serum of calf embryos - 20\% (Sigma, USA) with addition of $10 \mu \mathrm{l} / \mathrm{cm}^{3}$ of antibiotic-antimycotic medium. Cultivation was performed in a $\mathrm{CO}_{2}$ incubator at $37^{\circ} \mathrm{C}$ and $5 \% \mathrm{CO}_{2}$ concentration. In this case, the MSCs were deposited by attaching to the surface of the culture plates and petrified. The unattached cells were removed, after which only those cells having adhesive properties continued to be cultured. Microscopic analysis of the culture was performed using an inverted microscope Axiovert 40 (Carl Zeiss).

For the simulation of experimental osteoarthritis were used 27 male California rabbits (males), weighing between 2.8-3.3 kg. They were hosted in the steel cages, were fed with rabbit standard pellet diet and given water. Rabbits were divided into 3 groups ( 9 animals each): a control group; an experimental group and a second experimental group. Animals in the three groups were subjected to osteoarthritis of the knee joint by double injection of $3.44 \%$ retinol acetate into the joint cavity at a dose of $1 \mathrm{ml}$ at intervals of 7 days (Grillo 2004). After 28 days and the second injection of retinol acetate, animals in the control group were injected intra-articularly with $0.5 \mathrm{ml}$ of $0.9 \%$ isotonic sodium chloride solution; the first experimental group was treated subcutaneously with meloxicam injections $-0.4 \mathrm{mg}$ per $1 \mathrm{~kg} / \mathrm{bw}$ on the first day, with following injection of $0.2 \mathrm{mg}$ per $1 \mathrm{~kg} / \mathrm{bw}$ for 6 days (Di Salvo et al. 2016); animals of the second experimental group were administered intra-articular allogeneic mesenchymal stem cells (AMSC) at a dose of $3.5 \times 10^{6}$ cells, which were diluted in $0.5 \mathrm{ml}$ of phosphate buffer solution (FBS). Animals of the control, first and second experimental groups (9 animals each) were removed from the experiment on days 7, 14 and 28 of the experiment after the last injection of the drugs. For this purpose, animals were euthanized by intravenous injection of a lethal dose of $90 \mathrm{mg} / \mathrm{kg}$ thiopental natrium.

Control and experimental knees were exposed through interior parapatellar incision. After cutting the collateral and cruciform ligaments, they exposed the articular surface. The epiphyses of the bones forming the knee were removed by distal femoral and proximal tibiosteotomies and immediately fixed in $4 \%$ formaldehyde (just made of paraformaldehyde) in $0.1 \mu \mathrm{m}$ phosphate buffer $\mathrm{pH}$ 7.2. After removal of surrounding soft tissue decalcification was performed in 10\% EDTA-phosphate buffer at pH 7 and was put into paraffin. Histological 
sections were made in a sagittal projection and cut into $10-\mu \mathrm{m}$-thick sections. The sections were stained with Karatsi hematoxylin and eosin, examined under a light microscope and made microphotographs. The number of cells in the superficial area of articular cartilage of calculi was counted in seven fields of view of the microscope with magnification of the $x 40$ lens. Microscopic examination of the material was carried out using a microscope MSI 100 LED (Micros Austria).

\section{RESULTS}

Histological examination of the knee joints of the control group and the first experimental group of animals revealed nearly identical changes, with only minor differences.

On the 7th day, we found that the changes in the control and first study groups using traditional treatment were identical: distinct microscopic changes in articular cartilage and subchondral bone tissue. The microscopic changes in the cartilage and in the subchondral bone of the distal femoral epiphysis and the proximal tibial epiphysis were similar. The morphological features of the changed structure were found in the articular cartilage of the distal femoral epiphysis (Fig. 1a,b). Ulcers and flattening of the surface plate were observed. Degradation of the deeper layers was expressed in the integration of the matrix by cells associated with death (cytolysis) of chondrocytes, the appearance of cells with pycnotic nuclei, empty lacunae, disappearance of the columnar structure, chaotic placement of cartilage cells, edema.
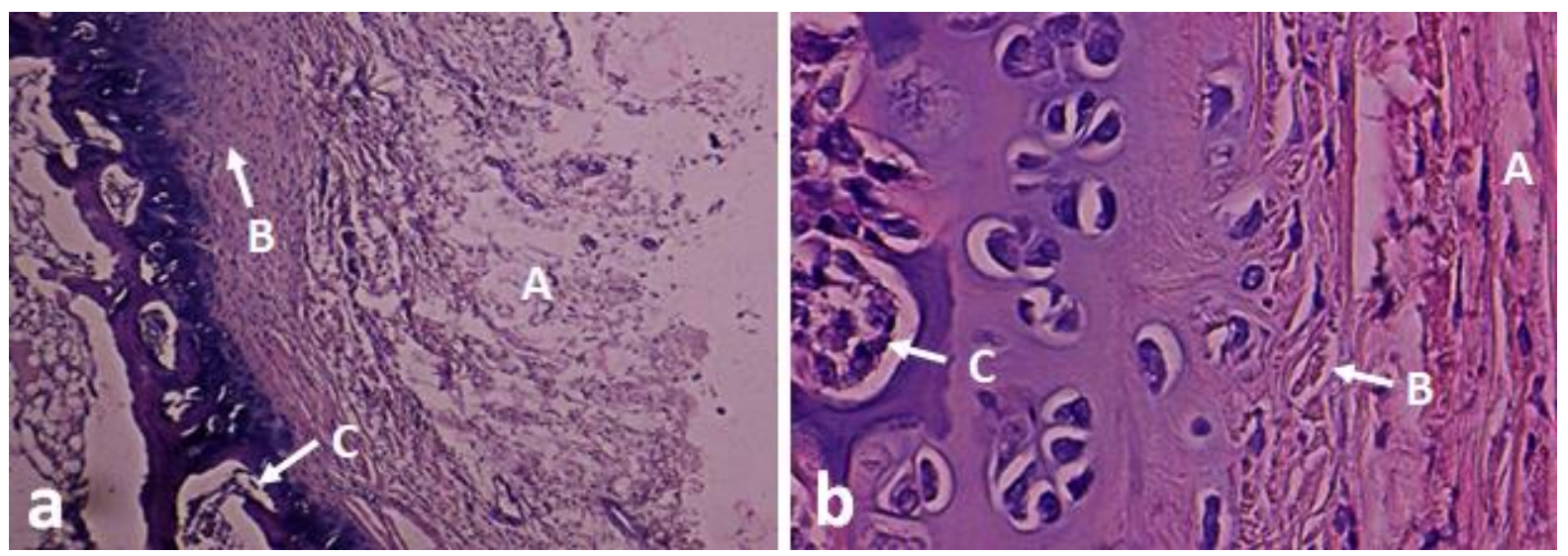

Fig. 1. Distal epiphysis of rabbit femur for 7 days: a) traditional treatment: $A$ - destroyed articular cartilage; B - decrease in the number of chondrocytes in the rest of the articular cartilage; $\mathrm{C}$ - thinning of bone tissue directly under the articular cartilage. Hematoxylin and eosin stain, magnification $\times 100$; b) after the introduction of $0.9 \% \mathrm{NaCl}$ : A - cartilage matrix; B - decay and lysis of cartilage matrix; $\mathrm{C}-$ necrosis and destruction of cartilage. Hematoxylin and eosin stain, magnification $\times 800$

On the 14th day, the animals from the first experimental group showed a slight improvement in the microscopic structure of the joint tissues. As on the 7th day of traditional treatment, the microscopic changes in the cartilage, subchondral bone, both in the proximal epiphysis of the femur and in the distal epiphysis of the tibia, were similar. The articular cartilage was unevenly thickened in the proximal femoral epiphysis and in the distal tibial epiphysis. Occasionally, it was over-thickened. In some relatively large areas of cartilage, its necrosis was recorded (Fig. 2a). In many areas of the articular cartilage, destruction of its superficial layers was recorded. It should be noted that the chondrocytes of cartilage had foamy 
cytoplasm, which indicated the active synthesis of substances. At the surface of the articular cartilage, large accumulations of necrotized and partially destroyed synoviocytes were found in places (Fig. 2b). The microscopic changes in bone tissue were similar to those at day 7 of traditional treatment.
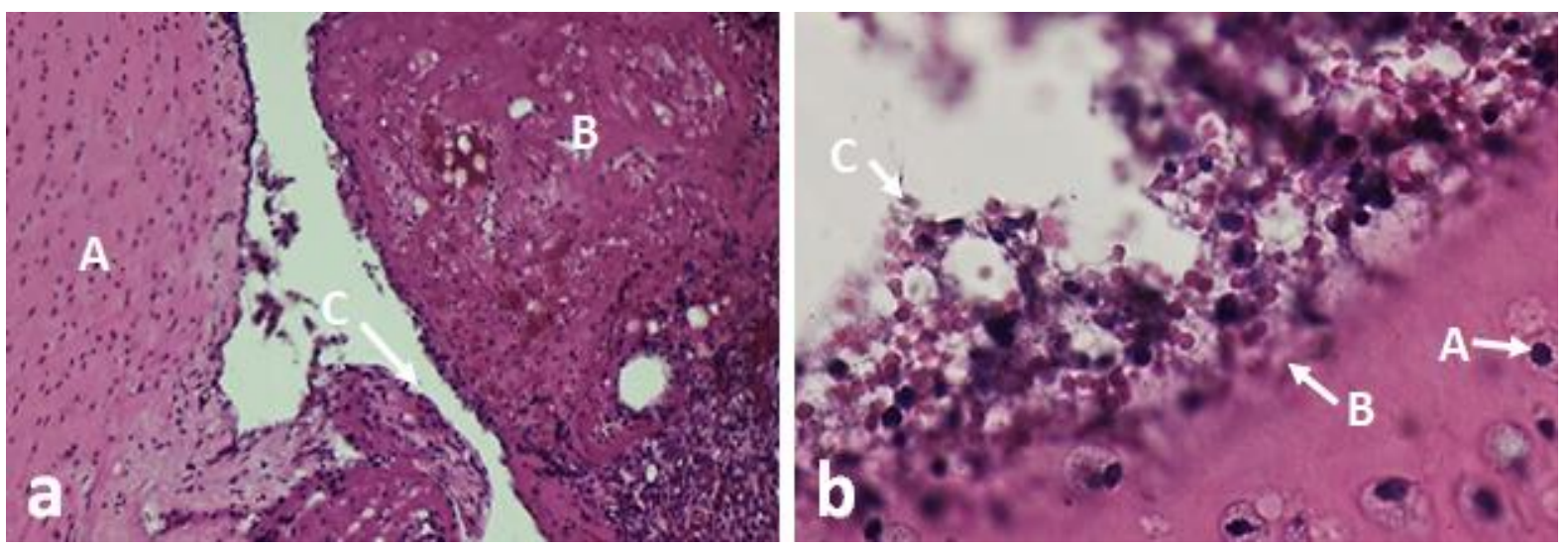

Fig. 2. Femur after 14 days of traditional treatment: a) distal epiphysis: $A$ - uneven thickening of the cartilage of the articular fossa; B - necrosis of the cartilage of the femoral head; C - a significant narrowing of the joint cleft. Hematoxylin and eosin stain, magnification $\times 100$; $b$ ) cartilage of the distal epiphysis: A - chondrocyte; B - destruction of the superficial layer of cartilage; C - necrosis and destruction of synoviocytes. Hematoxylin and eosin stain, magnification $\times 800$

At day 14 day after traditional treatment we established a clear activation of blood circulation in bone, as evidenced by dilated and blood-filled vessels of both arterial and venous beds In the bone marrow. In contrast, no changes were recorded in the control group of animals at day 14. At the same time, as in the 7th day of traditional treatment, the nature of microscopic changes in cartilage and subchondral bone in the proximal femoral epiphysis and the distal tibial epiphysis were similar. The articular cartilage in the proximal epiphysis of the femur and in the distal epiphysis of the tibia also thickened unevenly. The articular cleft had an uneven lumen and narrowed considerably in places. Necrosis of cartilage was registered (Fig. 3).

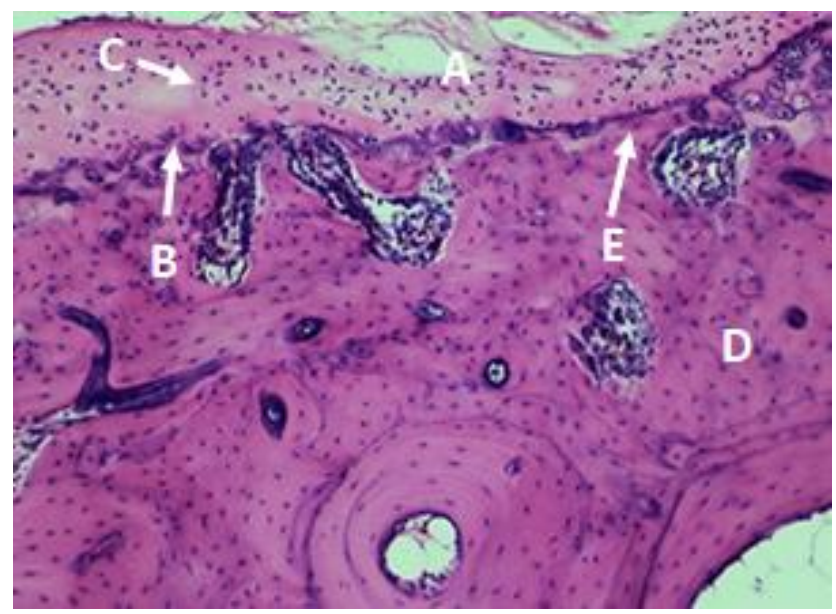

Fig. 3. Proximal femoral epiphysis of the control group rabbit for 14 days after administration of $0.9 \% \mathrm{NaCl}$ : A - destruction of the cartilage of the lower femoral epiphysis; B - uneven coloring of the basic substance of cartilage; C - uneven distribution of chondrocytes in cartilage; D - narrowed zone of endchondral osteogenesis; E - subchondral bone tissue. Hematoxylin and eosin stain, magnification $\times 100$ 
When conducting histological studies of the knee joint of the rabbits of the first experimental group on the 28th day of the experiment, we established a marked restoration of its microscopic structure, although the normal structure of the articular cartilage and subchondral bone tissue in this period of observations has not been restored. In the control group of rabbits on the 28th day of the experiment the restoration of the tissue structure of the knee joint was not observed. At the same time, necrosis and destruction of osteoblasts in the cell of spongy bone tissue were observed (Fig. 4b). The nature of the microscopic changes, as in the previous observation, in cartilage and subchondral bone in the proximal femur and distal tibia was similar in both groups. The articular cartilage for the use of Meloxicam in different areas had different thickness. From the outside, it was already covered with a perichondrium of a typical microscopic structure. In its deep layers were discovered single cavities of small size (Fig. 4a). The placement of cells in it was uneven. The latter were represented by both chondrocytes and fibroblasts. Part of the chondrocytes was localized in typical chambers, in some cases chondrocyte chambers did not differentiate. Subchondral bone tissue had a typical microscopic structure, but a large number of active osteoblasts was found in this spongy bone, indicating bone formation.
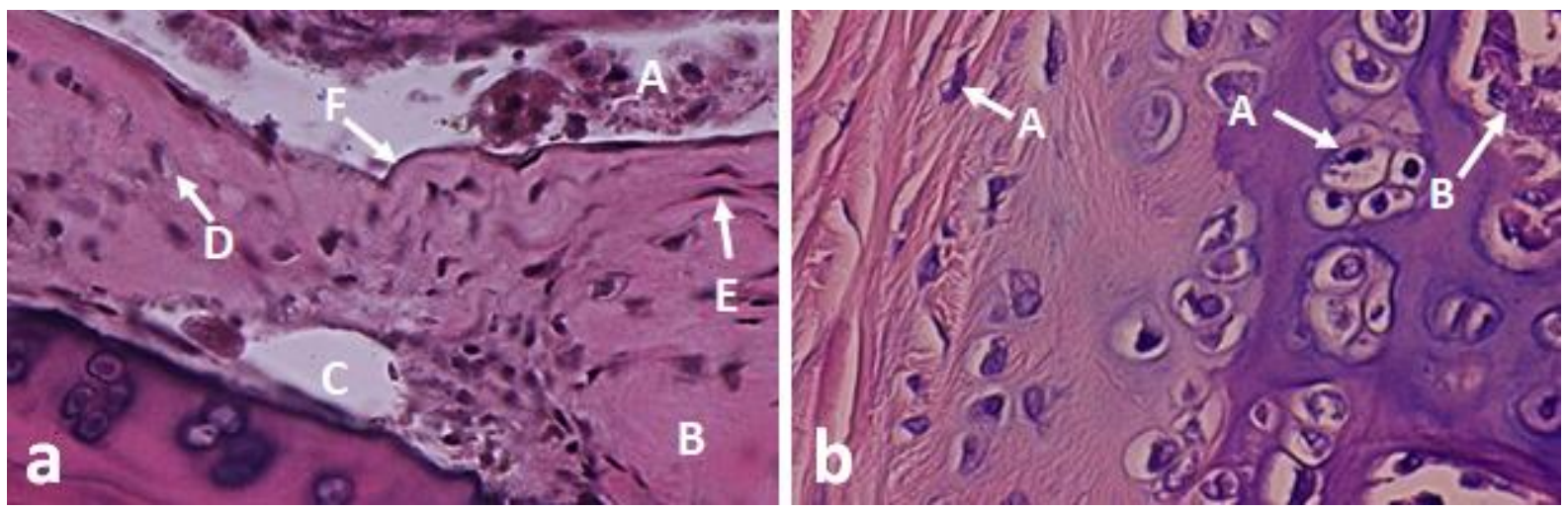

Fig. 4. Bone after 28 days: a) proximal epiphysis of the thigh bone of the rabbit for 28 days in traditional treatment: A - destroyed cartilage tissue in the joint cavity; B - articular cartilage; C - a cavity in the articular cartilage; D - chondrocyte; $\mathrm{E}$ - fibroblast; $\mathrm{F}$ - perichondrium. Carats hematoxylin and eosin $\mathrm{x}$ 800 ; b) distal epiphysis of the tibia of the knee of the rabbit control group after the introduction of $0.9 \%$ $\mathrm{NaCl}$ : A - destruction of chondrocytes; B - necrosis and destruction of osteoblasts in the spongy bone. Hematoxylin and eosin stain, magnification $\times 800$

When we conducted histological examinations of the knee joint of rabbits using MSC on the 7th day of the experiment, we established a significant restoration of the condition of all tissues of this joint compared with the animals of the first experimental group (using "Meloxicam"). At the same time, noticeable microscopic changes were registered in the articular cartilage and subchondral bone tissue. It should be noted that the nature of microscopic changes in cartilage, subchondral bone, both in the proximal epiphysis of the femur and in the distal epiphysis of the tibia was similar.

In histological preparations of cartilage were revealed signs of partial restoration of cartilage structure, which were expressed in the formation of chondrocytes of columns in the middle layer, slight renewal of the surface layer (increase in the number of cells), the appearance of isogenic groups of cartilage cells in the matrix. Matrix looks more homogeneous, with no signs of dislocation. 
The newly formed cartilage tissue was found on the surface of the bone tissue both in the proximal femur and in the distal epiphysis of the tibia, in which small cavities were registered in places (Fig. 5a). This newly formed tissue contained little more substance, and its cells were represented by chondroblasts contained in the chambers and in a relatively large number of fibroblasts. The presence of these cells indicates an active reparative process in the joint. In the deep layers of the newly formed cartilage, single blood capillaries were occasionally found, in the lumen of which erythrocytes were present (Fig. 5b).
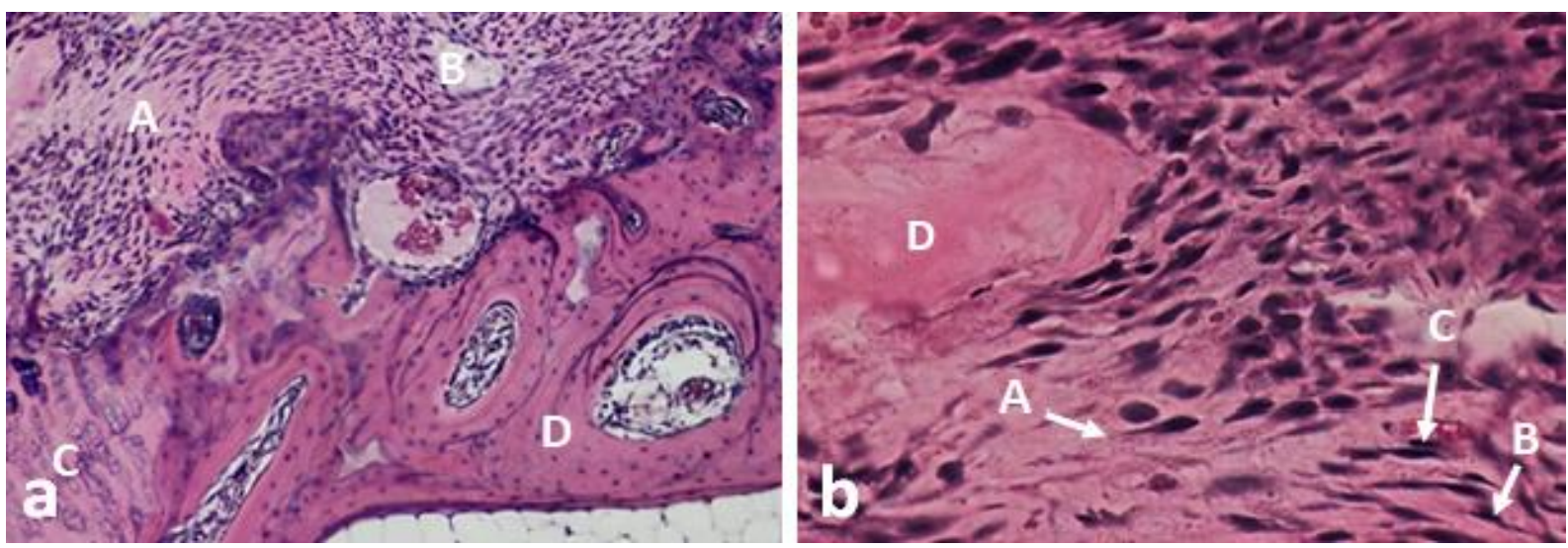

Fig. 5. Femur of rabbits for the 7th day of MSC: a) proximal epiphysis: A - newly formed cartilage tissue; $\mathrm{B}$ - a cavity in the newly formed cartilage tissue; C - zone of endochondral osteogenesis; D - bone tissue. Hematoxylin and eosin stain, magnification $\times 100 ; b)$ cartilage of the proximal epiphysis: A - chondroblast in the chamber; B - fibroblast; $\mathrm{C}$ - cartilage matrix; D - blood capillary. Hematoxylin and eosin stain, magnification $\times 800$

In the lacunas of the spongy bone, located directly below the articular cartilage, there were enlarged, blood-filled vessels and a large number of osteoblasts (Fig. 6). On the 14th day after MSC, articular cartilage, unlike the animals of the first experimental and control groups, resembled a typical hyaline cartilage in its microscopic structure. However, its articular surface was still uneven and the perichondrium was not clearly differentiated. Chondrocytes in the main substance were unevenly distributed. The cytoplasm of most of these cells was basophilic, indicating that they were active in protein synthesis. Occasionally, single, small-sized chondrocyte proliferation centers were registered, including single fibroblasts. In some parts of the articular cartilage, a rather wide area of endochondral osteogenesis was registered in its deep layers. The bone formed directly under the articular cartilage had heterogeneous density, as evidenced by the different intensity of eosin staining of the bone matrix. In the cells of the spongy bone under the articular cartilage was revealed a large number of osteoblasts, which indicates the regeneration of bone tissue (Fig. 6).

On the 28th day of the experiment in the animals of the second experimental group (after application of MSC), the microscopic structure of all the tissues of the knee, unlike the use of "Meloxicam", was already quite similar to that of intact animals. The articular cartilage had a flat articular surface and was covered with distinct perichondrium. However, compared to intact animals, its main substance was more basophilic. The majority of chondrocytes also had basophilic cytoplasm, indicating active formation of cartilage (Fig. 7ab). The microscopic structure and pattern of staining of the area of endchondral osteogenesis and subchondral bone tissue did not differ from that of intact rabbits. However, a large number of osteoblasts were still found in the lacunas located directly below the articular cartilage of the spongy bone (Fig. 7b). 


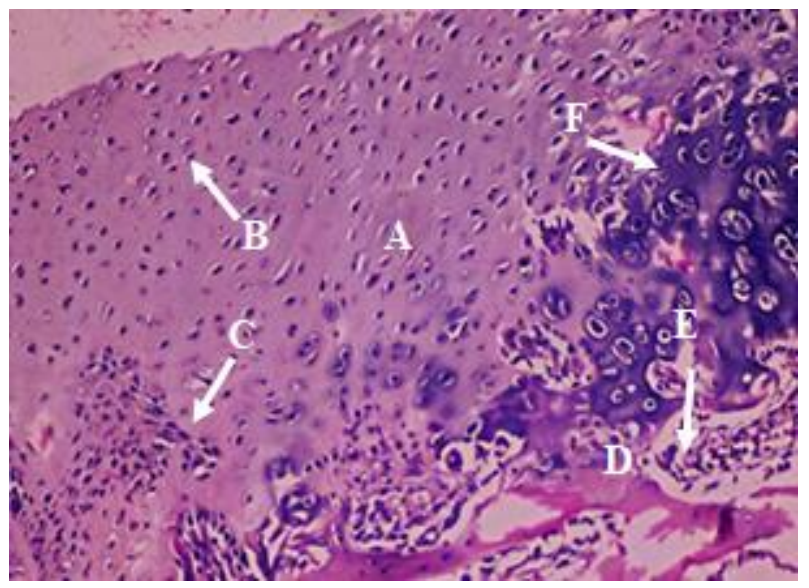

Fig. 6. Proximal epiphysis of rabbit femur for the 14th day of MSC: A - newly formed cartilage; $\mathrm{B}$ - chondrocytes; $\mathrm{C}$ - single fibroblasts in the foci of chondrocyte proliferation; $\mathrm{D}$ - zone of endochondral osteogenesis; E - bone tissue; F - osteoblasts. Hematoxylin and eosin stain, magnification $\times 100$
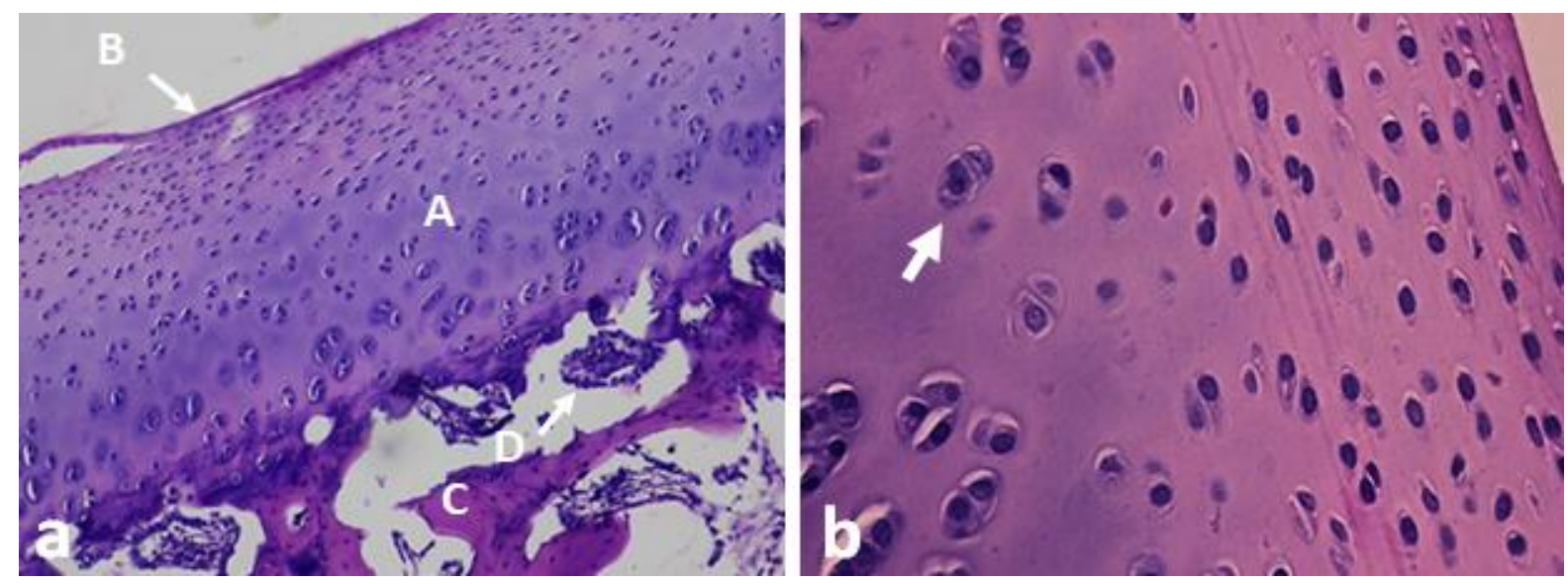

Fig. 7. Femur of rabbits for the $28 \mathrm{~h}$ day of MSC: a) proximal epiphysis: A - articular cartilage; $\mathrm{B}$ - perichondrium; C - bone tissue; D - osteoblasts. Hematoxylin and eosin stain, magnification $\times 100$; b) cartilage of the proximal femoral epiphysis: chondrocyte with basophilic cytoplasm (shown by arrow). Hematoxylin and eosin stain, magnification $\times 800$

Thus, our results indicate that the use of allogeneic MSCs at a dose of $3.5 \times 10^{6}$ cells in experimental osteoarthrosis of the knee joint of rabbits significantly accelerates reparative processes, unlike the use of "Meloxicam". Such positive changes in the knee joint of the second experimental group using MSCs are confirmed by the high activity of the processes of chondrogenesis and osteogenesis. Chondrogenesis is manifested by a large number of chondroblasts, which in turn are the precursors of chondrocytes from which cartilage is formed. And osteogenesis was manifested by the presence of osteoblasts, which in turn are mediators of osteocytes from which bone tissue is formed.

\section{DISCUSSION}

Our findings on the effect of allogeneic mesenchymal stem cells on reparative processes in the knee joint of rabbits with osteoarthritis are consistent with studies by several scientists. In particular, stem cells have been shown to accelerate the regeneration of all joint tissues by osteoarthritis (Nöth et al. 2008; Mobasheri et al. 2009; Mokbel et al. 2011; Sing 2012; Diekman et al. 2013; Mobasheri et al. 2014). 
On the 7th day of research, in the rabbits in the second experimental group (treated with allogeneic mesenchymal stem cells), we observed newly formed cartilage tissue, which corresponds to the second stage of chondrogenesis - the formation of primary cartilage. In the animals of the control and first experimental groups, was revealed that articular cartilage has been almost completely destroyed, also we revealed the collapse and lysis of individual sections of the main substance of hyaline cartilage.

On the 14th day of research, the transition from the second stage of chondrogenesis to the third stage was observed in the second experimental group, manifested by the differentiation of cartilage tissue and the formation of perichondrium. Active osteogenesis had also continued, manifesting in a wide area of endochondral osteogenesis and a large number of osteoblasts. It should be noted that the animals of the control group at this stage of the study did not observe a tendency to regenerate the articular cartilage. In the animals of the first experimental group, we observed the first stage of chondrogenesis - the formation of a chondrogenic islet. But this stage was not complete, as destruction of the superficial layers of articular cartilage was revealed.

On the 28th day of the study, the third stage of chondrogenesis - the differentiation of cartilage tissue, was recorded in the second experimental group, and full-fledged perichondrium was formed, but the process of repair of articular cartilage was still ongoing. A large number of osteoblasts have also been identified, indicating active bone repair. Continuation of articular cartilage necrosis was found in animals of the control group. In animals of the second experimental group the transition from the second stage of chondrogenesis to the third - differentiation of cartilage tissue was detected. The articular cartilage did not have the same thickness, and the placement of cells was uneven. However, a large number of osteoblasts have been identified, confirming active osteogenesis.

\section{CONCLUSIONS}

Local administration of allogeneic mesenchymal stem cells in experimental knee osteoarthritis increases the activity of regenerative processes and accelerates chondrogenesis and osteogenesis. Intraarticular injection of allogeneic mesenchymal stem cells activates cartilage formation as early as day 7 of the experiment, which manifests the formation of primary cartilage tissue corresponding to the second stage of chondrogenesis. In these animals, too, high activity of endochondral osteogenesis was found, confirming active regeneration in the knee joint with experimental osteoarthritis.

\section{REFERENCES}

Atala A., Lanza R., Thompson J., Nerem R. 2019. Principles of regenerative medicine. 3rd edition. Burlington, Elsevier, 405-416.

Bakker E., Stroobants V., VanDael F., Van Ryssen B., Meyer E. 2017. Canine synovial fluid biomarkers for early detection and monitoring of osteoarthritis. Vet. Rec. 180, 328-329.

Bijlsma J.W., Berenbaum F., Lafeber F.P. 2011. Osteoarthritis: an update with relevance for clinical practice. Lancet 377, 2115-2126.

Chaganti R.K., Lane N.E. 2011. Risk factors for incident osteoarthritis of the hip and knee. Curr. Rev. Musculoskelet Med. 4, 99-104. 
Di Salvo A., Giorgi M., Catanzaro A., Deli G., Rocca G. della. 2016. Pharmacokinetic profiles of meloxicam in turtles (Trachemys scripta scripta) after single oral, intracoelomic and intramuscular administrations. J. Vet. Pharmacol. Ther. 39, 102-105.

Diekman B.O., Guilak F. 2013. Stem cell-based therapies for osteoarthritis: challenges and opportunities. Curr. Opin. Rheumatol. 25, 119-126.

Felson D.T. 2006. Clinical practice. Osteoarthritis of the knee. N. Eng. J. Med. 354, 841-848.

Grillo M.G. 2004. Intra-articularin jection of vitamin A: a rabbit model to study osteoartrosis. Scand J. Lab. Anim. Sci. 31, 1-8.

Huey D.J., Hu J.C., Athanasiou K.A. 2012. Unlike bone, cartilage regeneration remains elusive. Science 338, 917-921.

Jones D.G., Peterson L. 2007. Autologous chondrocyte implantation, in: Cartilage repair strategies, ed. R.J. Williams. Totowa, New Jersey, Humana Press, 137-166.

Kladnytska L., Mazurkevych A., Bezdieniezhnykh N., Chekhun V., Melnyc O., Velychko S., Malyuk M., Kozycka T., Kovak V., Danilov V., Kharkevych Y., Gryzinska M. 2020. The Expression of Cytoplasmic and Membrane Proteins in Dog Adipose-Derived Stem Cells on Different Passages During Cultivation in Vitro. Pak. J. Zool. 52, 1547-1553.

Kolf C.M., Cho E., Tuan R.S. 2007. Mesenchymal stromal cells. Biology of adult mesenchymal stem cells: regulation of niche, self-renewal and differentiation. Arthritis Res. Ther. 9, 204.

Law of Ukraine. 2006. On protection of animals against cruel treatment No. 27, 230, https://zakon.rada.gov.ua/laws/show/3447-15\#Text. [in Ukrainian]

Maury E.E., Flores R.H. 2006. Acute monarthritis: diagnosis and management. Prim/ Care. 33, 779-793.

Mazurkevych A., Jakubczak A., Malyuk M., Bezdieniezhnykh N., Starodub L., Kharkevych Y., Gryzinska M. 2017. Immunophenotypic characteristics and karyotype analysis of bone marrowderived mesenchymal stem cells of rabbits during in vitro cultivation. Pol. Vet. Sci. 20, 687-695.

Mazurkevych A., Malyuk M., Bezdieniezhnykh N., Starodub L., Kharkevych Y., Brusko E., Gryzinska M., Jakubczak A. 2016. Immunophenotypic characterization and cytogenetic analysis of mesenchymal stem cells from equine bone marrow and foal umbilical cords during in vitro culture. J. Vet. Res. 60, 339-347.

Mazurkevych A., Malyuk M., Kovpak V., Kovpak O., Kharkevych Y., Jakubczak A., Gryzinska M. 2018. Comparative analysis of cat bone marrow and adipose tissue cell cultures. Pol. Vet. Sci. 21, 549-557.

Melero-Martin J.M., AI-Rubeai M. 2007. In vitro expansion of chondrocytes. Top. Tiss. Eng. 3, 3-37.

Mobasheri A., Csaki C., Clutterbuck A.L., Rahmanzadeh M., Shakibaei M. 2009. Mesenchymal stem cells in connective tissue engineering and regenerative medicine: applications in cartilage repair and osteoarthritis therapy. Histol. Histopathol. 24, 347-366.

Mobasheri A., Kalamegame G., Musumecif G., Batt M. 2014. Chondrocyte and mesenchymal stem cell-based the rapies for cartilage repair in osteoarthritis and related orthopaedic conditions. Maturitas 78, 188-198.

Mokbel A.N., El Tookhy O.S., Shamaa A.A., Rashed L.A., Sabry D., El Sayed A.M. 2011. Homing and reparative effect of intra-articular injection of autologus mesenchymal stem cells in osteoarthritic animal model. BMC Musculoskelet Disord. 12, 259.

Montoya F., Martínez F., García-Robles M., Balmaceda-Aguilera C., Koch X., Rodríguez F., Silva-Álvarez C., Salazar K., Ulloa V., Nualart F. 2013. Clinical and experimental approaches to knee cartilage lesion repair and mesenchymal stem cell chondrocyte differentiation. Biol. Res. 46, 441-451.

Musumeci G., Castrogiovanni P., Leonardi R., Trovato F.M., Szychlinska M.A., Di Giunta A., Loreto C., Castorina S. 2014. New perspectives for articular cartilage repair treatment through tissue engineering: A contemporary review. World J. Orthop. 5, 80-88. 
Nöth U., Steinert A.F., Tuan R.S. 2008. Technology Insight: adult mesenchymal stem cells for osteoarthritis therapy: Delivery modes for Mesenchymal stem cells. Nat. Clin. Pract. Rheumatol. 4, 371-380.

Singh J.A. 2012. Stem cells and other innovative intra-articular therapies for osteoarthritis: what does the future hold? BMC Med. 10, 44.

\title{
ZMIANY MORFOLOGICZNE W TKANKACH STAWU KOLANOWEGO KRÓLIKA SPOWODOWANE CHOROBA ZWYRODNIENIOWA STAWÓW PO ZASTOSOWANIU EKSPERYMENTALNEJ METODY WYKORZYSTUJACCEJ MEZENCHYMALNE KOMÓRKI MACIERZYSTE
}

\begin{abstract}
Streszczenie. Celem pracy było zbadanie procesów regeneracyjnych w stawie kolanowym królików z chorobą zwyrodnieniową stawów po eksperymentalnym zastosowaniu allogenicznych komórek macierzystych szpiku kostnego i tradycyjnym leczeniu niesteroidowym lekiem przeciwzapalnym Meloksykam. Do doświadczenia użyto 27 królików kalifornijskich (samców). Utworzono trzy grupy zwierząt: grupę kontrolną, pierwszą grupę eksperymentalną leczoną metodą tradycyjną, drugą grupę eksperymentalną leczoną allogenicznymi mezenchymalnymi komórkami macierzystymi (MSC). Zwierzęta z trzech grup poddawano chorobie zwyrodnieniowej stawu kolanowego poprzez podwójne wstrzyknięcie 3,44\% octanu retinylu do jamy stawu, w dawce $1 \mathrm{ml}$, w odstępach 7-dniowych. Tkanki z zajętego miejsca pobierano do badania histologicznego po 7, 14 i 28 dniach. Skrawki histologiczne wybarwiono hematoksyliną-eozyną i zbadano pod mikroskopem. Ustalono, że dostawowe podanie 3,5 × $10^{6}$ komórek allogenicznych MSC w eksperymentalnie wywołanej chorobie zwyrodnieniowej stawów przyczynia się do odbudowy powierzchowniowej warstwy chrząstki, o czym świadczy tworzenie się słupków chondrocytów w środkowej warstwie chrząstki stawowej oraz wygląd izogenicznych grup komórek chrząstki z bazofilną cytoplazmą w macierzy i jednolita powierzchnia stawowa. Stosowaniu tradycyjnej metody leczenia królików lekiem Meloksykam towarzyszy niepełna chondrogeneza; część chondrocytów zlokalizowana jest w typowych komorach; w niektórych przypadkach komory chondrocytów nie różnicowały się; chrząstka stawowa miała niejednakową grubość, rozmieszczenie komórek było nierównomierne.
\end{abstract}

Słowa kluczowe: króliki, staw kolanowy, szpik kostny, mezenchymalne komórki macierzyste, choroba zwyrodnieniowa stawów. 
